\title{
MENINGKATKAN KEMAMPUAN GURU AGAMA KATOLIK TK. SMA MENYUSUN INSTRUMEN PENILAIAN BERBASIS HOTS MELALUI PENDAMPINGAN PENGAWAS DI MGMP KOTA MEDAN
}

\author{
Pitna Simanjuntak
}

Surel: silviapitna@gmail.com

\begin{abstract}
This study aims to improve the ability of teachers to develop HOTS-based assessment instruments through the assistance of supervisors at the Medan Catholic High School MGMP. T.P 2020/2021. This study uses the PTS method (school action research) with two cycles. The data collection tools were questionnaires and checklists with five alternative answers according to the Likert scale. The collected data were analyzed descriptively by percentage. The results of data analysis showed that the teacher's ability to develop HOTS-based assessment instruments before the action got an average score of 75 in the sufficient category, after action I increased to an average value of 87 in the good category, and after action II increased again with an average value of 92 in the very good category. . The implementation of research assistance as a Catholic religious teacher has increased, in the first cycle the average score was 73 in the sufficient category, and after the action in the second cycle, the average value was 87 in the good category. So, it can be concluded that Catholic religion teachers at the high school level in the city of Medan have the ability to develop HOTS-based assessment instruments very well. Through the assistance of researchers as supervisors of Catholic religious teachers in the city of Medan.
\end{abstract}

Keywords: HOTS-based instrument, PTS

\begin{abstract}
ABSTRAK
Penelitian ini bertujuan untuk meningkatkan kemampuan guru menyusun instrumen penilaian berbasis HOTS melalui pendampingan pengawas di MGMP SMA katolik Medan. T.P 2020/2021. Penelitian ini menggunakan metode PTS (penelitian tindakan sekolah) dengan dua siklus. Alat pengumpulan datanya adalah angket dan cheklis dengan lima alternatif jawaban sesuai skala Likert.Data yang terkumpul dianalisis secara deskriptif persentatif. Hasil analisis data menunjukkan bahwa kemampuan guru menyusun instrumen penilai berbasis HOTS sebelum tindakan mendapat nilai rata rata 75 dengan kategori cukup, setelah tindakan I meningkat dengan nilai rata 87 pada kategori baik, dan setelah tindakan II meningkat lagi dengan nilai rata rata 92 dengan kategori sangat baik. Pelaksanaan pendampingan peneliti sebagai pengawas guru agama katolik mengalami peningkatan, pada siklus I mendapat rerata nilai 73 dengan kategori cukup, dan setelah tindakan pada siklus II mendapat rerata nilai 87 dengan kategori baik. Maka, dapat disimpulkan bahwa guru agama katolik tingkat SMA di kota Medan telah memiliki kemampuan menyusun instrumen penilaian berbasisi HOTS secara sangat baik. Melalui pendampingan peneliti sebagai pengawas guru agama katolik di kota Medan.
\end{abstract}

Kata Kunci: Instrumen berbasis HOTS, PTS 


\section{PENDAHULUAN}

Menurut Undang-Undang Nomor 14 Tahun 2005 tentang Guru dan Dosen serta Peraturan Pemerintah Nomor 19 Tahun 2005 tentang Standar Nasional Pendidikan, guru memiliki peran strategis dalam bidang pendidikan.Tanpa guru yang berkualitas dan profesional, sulit untuk meningkatkan mutu pendidikan. di Indonesia. Dengan kata lain, guru merupakan garda depan dalam upaya peningkatan mutu pelayanan dan hasil pendidikan. Oleh karena itu, peningkatan kualitas pendidikan harus dicapai melalui upaya peningkatan kemampuan mengajar dan kualitas profesional guru. Salah satu implementasinya adalah menghasilkan soal-soal berorientasi HOTS berbasis keterampilan berpikir kritis untuk percepatan pendidikan.

Mulyono (2012) berkata, kompetensi guru dalam penyusunan Soal Higher Order Thinking Skills yaitu kemampuan berpikir tingkat tinggi (HOTS) para siswa, maka banyak upaya telah dilakukan oleh pemerintah Indonesia untuk melakukan perbaikan. Upaya- upaya tersebut di antaranya melakukan perubahan atau revisi kurikulum secara berkesinambungan, program kemitraan antara sekolah dengan stakeholder.

Selanjutnya ditegaskan para praktisi Sanjaya (2006) memasuki Abad 21, Sumber Daya Manusia dituntut memiliki beberapa kemampuan, seperti kemampuan berpikir tingkat tinggi, kreatif, terampil, mampu memahami berbagai budaya dan mempunyai kemampuan berkomunikasi serta mampu belajar sepanjang hayat (life long learning). Dari beberapa tuntutan di atas, kemampuan berpikir tingkat tinggi merupakan salah satu kemampuan yang semestinya dikuasi oleh suberdaya manusia "peserta didik". Untuk itu proses pembelajaran yang dilakukan agar diupayakan menjamin pembentukan kemampuan berpikir tingkat tinggi secara optimal. Selain itu, pengembangan kemampuan berpikir tingkat tinggi (HOTS) pada siswa merupakan masalah yang mendesak dalam dunia pendidikan modern. HOTS merupakan tingkat berpikir yang menitikberatkan pada penerapan pengetahuan yang diperoleh, berpikir, memecahkan masalah, mengambil keputusan dan kemudian merumuskan sesuatu yang baru. Ini adalah bagian penting dari apa yang harus diajarkan di kelas dalam kaitannya dengan konteks pendidikan yang mengarah pada berbagai ide tentang strategi yang terkait dengan mendukung proses berpikir yang lebih tinggi. Hal ini karena Higher Order Thinking Skills (HOTS) merupakan landasan belajar sesuai dengan esensinya: proses, produk, dan sikap. Oleh karena itu, menurut hakikat belajar, idealnya adalah kegiatan belajar yang memungkinkan siswa untuk memaksimalkan potensi berpikirnya. Melalui berpikir tinggi (HOTS) dan pembelajaran berdasarkan 
pengukuran HOTS, siswa diharapkan lebih kritis, kreatif, inovatif dan mampu memecahkan masalah yang dihadapinya.

Proses pembelajaran yang mengacu pada pembentukan higher order thingking skills ini (hots) harus dideskripsikan dan dirumuskan pada setiap komponen pembelajaran sebagai suatu sistem. Seperti pada rumusan pada kompenen indikator, rumusan tujuan, maupun deskripsi kegiatan pembelajaran dan penilaiannya secara terpadu didalam desain pembelajaran itu sendiri (RPP). Artinya pendidik sebagai sumber daya manusia harus memiliki kemampuan untuk secara profesional mengembangkan dan mentransformasi pembelajaran yang masih merupakan keterampilan berpikir tingkat rendah (LOTS) menjadi keterampilan berpikir tingkat tinggi (HOTS). Demikian pula, guru dituntut untuk mampu mengembangkan perangkat penilaian berbasis Higher Order Thinking Skills (HOTS). Oleh karena itu pengawas ingin meningkatkan keterampilan guru menciptakan pembelajaran berbasis hots sehingga siswa sebagai SDM kelak mampu berkiprak sesuai perkembangan IPTEK.

Penilaian merupakan merupakan salah satu komponen pembelajaran yang tidak kalah urgensinya dengan komponen lainnya. Melalui penilaian, pendidik sebagai pemimpin instruksional dapat menilai kemampuan peserta didik, ketepatan metode pengajaran yang digunakan, dan kemajuan peserta didik menuju kompetensi tertentu. Berdasarkan hasil penilaian tersebut, pendidik dapat mengambil keputusan yang tepat untuk menentukan langkah apa yang harus diambil. Hasil penilaian juga dapat memotivasi siswa untuk meningkatkan prestasinya, baik itu ulangan harian, ulangan tengah semester, maupun ulangan peningkatan prestasi.

Pelaksanaan proses pembelajaran di kelas hanya ditujukan pada kemampuan siswa dalam menghafal informasi, otak siswa dipaksa untuk menghafal dan menimbun segala macam informasi tanpa memahami informasi yang telah diperolehnya. Studi yang telah diselesaikan tidak dibatasi agar siswa dapat belajar bagaimana belajar. Menurut pilar pendidikan, salah satu masalah yang dihadapi dunia pendidikan saat ini adalah buruknya pelaksanaan proses pembelajaran yang diterapkan oleh guru sekolah. Proses pembelajaran yang berlangsung selama ini gagal mengembangkan kemampuan berpikir tingkat tinggi (HOTS) siswa. Hasil TIMSS (Salah satu studi Internasional mengenai kemampuan kognitif siswa yaitu TIMSS (Trends in Mathematics and Science Study dalam Nurlaela (2015) disimpulkan bahwa kemampuan berpikir tingkat tinggi siswa Indonesia masih rendah. Hal ini terjadi karena dalam peroses pembelajaran di sekolah, siswa Indonesia pada umumnya kurang dirangsang untuk meningkatkan kemampuan berpikir tinggi. Sementara kemampuan berpikir 
kreatif sangat di perlukan agar kompetensi sumber daya menusia kita tidak kalah dengan bangsa lain.

Selanjutnya Mulyasa (2003)

berkata bahwa pendidikan belum mampu menghasilkan SDM yang berkualitas. Dengan alasan: (1) guru masih menunjukkan kinerja yang rendah dalam mengajar oleh karena pemahaman guru akan strategi mengajar masih sangat kurang. Juga Sagala (2007) berkata : kinerja guru terkesan kurang optimal, guru melakukan tugasnya hanya sebagai kegiatan rutin, innovasi bagi guru relatif tertutup,dan kreativitas bukan bagian dari prestasi. Dari sisi lain Tan (2000) dalam Rusman (2011) berkata tidak semua guru memahami konsep pembelajaran dengan benar, baik itu disebabkan oleh kurangnya keinginan dan motivasi untuk meningkatkan kualitas keilmuan maupun karena kurangnya dukungan system untuk meningkatkan kualitas keilmuan tenaga pendidik. Itu makanya Sanjaya (2006) berkata ada kekeliruan guru dalam melakukan proses pembelajaran diantaranya (1) proses pembelajaran tidak mengajak siswa berpikir aktif dalam proses pembelajaran, dsb. Artinya

Pelaksanaan proses pembelajaran yang berlangsung di dalam kelas hanya diarahkan pada seberapa baik siswa menghafal informasi, otak siswa dipaksa untuk mengingat dan menimbun berbagai informasi tanpa dituntut untuk memahami informasi yang diperoleh untuk menghubungkan dengan situasi menyatakan bahwa guru dituntut memiliki kemampuan dalam penilaian secara komprehensif baik pada tataran konseptual atau praktik Secara empris pandangan tersebut di atas mendapat dukungan,saat pengawas melakukan kunjungan ke beberapa sekolah tingkat SMA di kota Medan, tampak bahwa pelaksanaan pembelajaran belum menggambarkan hots, bahkan desain rencana pembelajaran (RPP) belum menggambarkan hots (Higher Order Thingking Skill) mulai dari perumusan indikator, tujuan pembelajaran, kegiatan inti maupun pengembangan instrumen penilaan

- Oleh karena itu proses pembelajaran yang dikondisikan belum menjadikan siswa aktif memecahkan masalah, belum mampu mempertahankan pendapat, dan belum terbiasa menyelesaikan soal-soal yang memerlukan keterampilan berpikir siswa. Rumusan instrumen penilaian juga tidak lagi mengacu pada kemampuan berpikir kreatif, sehingga kualitas proses pembelajaran masih rendah, keberanian siswa dalam bertanya, mengemukakan pendapat, menjawab pertanyaan dilihat dari standar proses. Secara simultan hasil penilaian atas capaian pembelajaran belum menjanjikan pada tuntutan 4.0 dan abad ke -21 sebagaimana mestinya.

Kita telah melihat bahwa soal-soal tes kompetensi Pendidikan Agama Katolik untuk sekolah sangat membingungkan. Ditemukan bahwa penyusunan tes dan pengembangan item masih belum valid dan reliabel. Dalam melaksanakan ulangan harian, ulangan tengah semester, dan ulangan 
semester, guru hanya menyalin soal dari LKS dan atau menyalin dari buku lain tanpa memperhatikan apakah soal sudah sesuai dengan indikator dan kompetensi dasar. ditentukan atau tidak. Mereka mengembangkan soalsoal yang terkesan asal-asalan dan tidak sesuai dengan indikator dan kompetensi dasar yang telah ditentukan. Paling patalnya tidak jarang guru mengembangkan tes tanpa menggunakan langkah-langkah, seperti (1) menentukan tujuan penilaian, (2) menentukan kompetensi yang diujikan (3) menentukan materi penting pendukung kompetensi (urgensi, kontinuitas, relevansi, keterpakaian), (4) menentukan jenis tes yang tepat (tertulis, lisan, perbuatan), (5) menyusun kisi-kisi, butir soal, dan pedoman penskoran, (6) melakukan telaah butir soal. Dengan kata lin instrumen yang mereka kembangkan amburadul tanpa tujuan dan kisi-kisi yang jelas. Dari temuan temuan tersebut, jelas guru agama katolik di kota Medan, belum terampil mengembangkan atau menyusun instrumen penilaian secara baik, terutama pengembangan instrumen yang bertolak dari kemampuan berpikir tinggi "Higher Order Thingking Skill) “(HOTS).

Sebagai salah satu tupoksi pengawas adalah untuk membantu guru mengatasi permasalahan yang ada dilapangan,guna meningkatkan kemampuan guru melakukan pembelajaran sesuai tuntutan zaman dan kebutuhan para pengguna. Untuk itulah maka pegawas ingin mendampingi guru agama meningkatkan keterampilannya menyusun instrumen berbasis hots berdasarkan indikator dan tujuan pembelajaran yang digariskan dalam desain RPP. Sehingga siswa sebagai SDM kelak memiliki keterampilan berpikir kritis, analitis, dan kreatif sesuai perkembangan IPTEK. Oleh karena itu maka judul PTS ini ditetapkan berikut: Meningkatkan Kemampuan Guru Agama Katolik Tk. SMA Menyusun Instrumen Penilaian Berbasisi HOTS Melalui Pendampingan Pengawas di MGMP Kota Medan. TP 2020/2021.

\section{METODE PENELITIAN}

Jenis penilitian ini adalah Penelitian Tindakan Sekolah (PTS) secara kolaboratif. Dengan mengembangkan penyusunan instrumen berbasisi HOTS .Dalam rancangannya, penelitian ini dilakukan dengan 2 siklus. Sedangkan kolaborasinya adalah: (1) pengawas sebagai peneliti, (2) pengawas lainnya 2 orang berperan sebagai observer dan guru sebagai subjek didik/sasaran. Hasil penelitian kelak akan dibicarakan bersama tim,guna menentukan nilai atau hasil tindakan serta menentukan apakah dilanjutkan pada siklus berikutnya. Subjek dalam penelitian adalah guru-guru agama katolik di SMAkota Medan, Tahun ajaran 2020/2021 sebanyak 18 orang guru. Sedangkan objek penelitiannya adalah penyusunan instrumen berbasisi HOTS. Teknik pengumpulan data dalam penelitian ini adalah lembar observasi dan dokumentasi. 


\section{HASIL PENELITIAN DAN} PEMBAHASAN

Mengenai

peningkatkan

Kemampuan guru menyusun Instrumen Penilaian Berbasis HOTS dalam pembelajaran agama Katolik dan pendampingan pengawas di SMA kota Medan.Terbukti secara empiris sama-sama mengalami peningkatan. Hal ni dibuktikan bahwa Kemampuan guru menyusun Instrumen Penilaian Berbasis HOTS dalam pembelajaran agama Katolik sebelum tindakan masih tergolong cukup dengan nilai rata-rata 75 , stelah siklus I ada peningkatan dengan kategori baik pada nilai rata-rata 87, kemudian setelah siklus II meningkat lagi menjadi kategori sangat baik dengan nilai rata-rata 92. Selanjutnya nilai pendampingan pengawas selama penelitian menunjukkan peningkatan yang kontinu. Hal itu dibuktikan dengan nilai pendampingan pengawas pada siklus I tergolong cukup dengan nilai rata rata 73 , selanjutnya setelah siklus II terdapat peningkatan dengan nilai rata rata 87 pada kategori baik.

Pengujian hipotesis tindakan yang berbunyi Kemampuan guru menyusun Instrumen Penilaian Berbasis HOTS dalam pembelajaran agama Katolik dapat meningkat melalui pendampingan pengawas di SMA kota Medan. Secara deskriptif diterima. Karena Kemampuan guru menyusun Instrumen Penilaian Berbasis HOTS dalam pembelajaran agama Katolik mendapat rerata nilai 92 dengan kaegori sangat baik. Demikian juga pelaksanaan pendampingan peneliti sebagai pengawas memperoleh nilai 87 pada kategori baik. Artinya hasil yang dicapai melalui penelitian ini telah berhasil melampaui target yang telah ditetapkan.

\section{Pembahasan}

Kemampuan guru menyusun Instrumen Penilaian Berbasis HOTS dalam pembelajaran agama Katolik dinyatakan dalam aspek:

- Indikator dan tujuan pembelajaran sesuai dengan instrumen penilaian secara holistik,

- Kemampuan kritis dengan Tes infrensi; Tes Penerimaan Asumsi; Tes Mebuat peringkat,

- Kemampuan Kreatif dengan Tes Kreasi gambar,Tes Deskripsi; Tes Melengkapi gambar

- Pilihan Ganda dengan bentuk: Tes mengenal istilah/nama orang:Tes membandingkan: Tes sebab akibat; Tes generalisasi; Tes kronologi; Tes membedakan fakta;Tes kerangka acuan;Tes penggunaan sumber;Tes penggunaan refrensi

- TIMSS/PISA

- Tes Berbasis Masalah Mengenal masalah dalam bentuk: Mendefenisikan masalah: Menjelaskan makna melalui observasi; Mencari solusi dgn mind mapping; Mencasi solusi dgn analisis sebab akibat; Berpikir deduktif; Berpikir induktif dan Membedakan argumen dgn penjelasan.

Demikian juga pendampingan peneliti sebagai pengawas,telah 
dilakukan dengan baik sesuai dengan tujuan yang telah ditetapkan dalam program supervise. Bila dikaji lebih jauh ,hasil penelitian ini mendapat dukungan secara teoritis, hubungannya Natisemito (1982)) menyatakan "pendampingan/pelatihan atau training adalah suatu kegiatan yang bermaksud untuk dapat memperbaiki dan memperkembangkan sikap, tingkah laku, keterampilan dan pengetahuan dari para karyawan, sesuai dengan keinginan". Lebih lanjut Sedarmayanti (2010: 169) berkata tujuan pendampingan/pelatihan adalah "(1) meningkatkan produktifitas dalam jumlah maupun mutu; (2) mengurangi kecelakaan; (3) mengurangi pengawasan;

meningkatkan stabilitas organisasi; (5) pemborosan dan kerusakan berkurang; (6) menambah pengetahuan; (7) menambah keterampilan". Dalam konteks Kemampuan guru menyusun Instrumen Penilaian Berbasis HOTS dalam pembelajaran agama Katolik

\section{SIMPULAN}

Secara deskriptif, pelaksanaan pendampingan pengawas agama katolik di SMA kota Medan pada siklus I tergolong cukup dengan rerata nilai 73, setelah siklus II meningkat pada kategori baik dengan rerata nilai 87 .

Kemampuan guru agama menyusun Instrumen Penilaian Berbasis HOTS dalam pembelajaran agama Katolik sebelum tindakan tergolong cukup dengan nilai 75 ; setelah siklus I meningkat pada kategori baik dengan rerata nilai 87; dan setelah siklus II meningkat lagi pada kategori sangat baik dengan rerata nilai 92 .

Dari analisis data penelitian tersebut, disimpulkan bahwa peningkatan pelaksanaan pendampingan guru yang dilakukan oleh pengawas sepadan dengan peningkatan kemampuan guru menyusun Instrumen Penilaian berbasis HOTS dalam pembelajaran agama Katolik di Kota Medan. Secara simultan beriringan dan atau berpadanan dengan peningkatan pelaksanan pendampingan atas dasar peningkatan kompetensi peneliti sebagai pengawas SMA di kota Medan.

\section{DAFTAR RUJUKAN}

Abdullah Sani, Ridwan. 2019. Pembelajaran Berbasis HOTS (Higher Order Thinking Skills). Tangerang: Tira Smart.

Akbar, Sa'dun. 2013. Instrumen Perangkat Pembelajaran. Bandung: Rosdakarya. Atmojo, W. R., Sajidan, Sunarno, W., \& Ashadi. 2017. Profil Kemampuan Menganalisis Model Pembelajaran Level of Inquiry Untuk Membelajarkan Materi IPA Berbasis. SEMINAR NASIONAL PENDIDIKAN SAINS. 1-6. Retrieved from Ilmiah, S., Siswa, I. P. A., \& Kererobbo, S. D. K. 2013. The Effect of the Implementation of the 4-E Learning Cycle on the Knowledge, Basic Process Skills 
Pitna Simanjuntak : Meningkatkan Kemampuan Guru ...

and Scientific Attitude, (1), 4350.

M., U. Usman. 2002. Menjadi Guru Profesional. Bandung: Remaja Rosda Karya.

Nurlaela, Luthfiyah, dkk. 2015. Strategi Belajar Berpikir Kreatif. Surabaya: Ombak.

Rusman, 2012. Model-Model pembelajaran: Mengembangkan Profesionalisme. Jakarta: Raja Grafindo Persada.

Sagala, Syaiful. 2012. Konsep dan makna Pembelajaran. Bandung: Alfabeta.

Sanjaya, Wina. 2006. Strategi Pembelajaran Berorientasi Standar Proses Pendidikan. Jakarta: Kencana Prenadamedia Group

Siegel, Sidney. 1992. Statistik Nonparametrik Untuk Ilmu-Ilmu Sosial. Jakarta: Gramedia

Sudarwan, Danin. 2006. Visi Baru Manajemen Sekolah: dari Unit Borokrasi ke Lembaga Akademik. Jakarta: Bumi Aksara 